Contracting Female Marriage in Anthony Trollope's Can You Forgive Her?

Review by: SHARON MARCUS

Nineteenth-Century Literature, Vol. 60, No. 3 (December 2005), pp. 291-325

Published by: University of California Press

Stable URL: http://www.jstor.org/stable/10.1525/ncl.2005.60.3.291

Accessed: 20/02/2013 16:42

Your use of the JSTOR archive indicates your acceptance of the Terms \& Conditions of Use, available at http://www.jstor.org/page/info/about/policies/terms.jsp

JSTOR is a not-for-profit service that helps scholars, researchers, and students discover, use, and build upon a wide range of content in a trusted digital archive. We use information technology and tools to increase productivity and facilitate new forms of scholarship. For more information about JSTOR, please contact support@jstor.org. 


\title{
Contracting Female Marriage in Anthony Trollope's Can You Forgive Her?
}

\author{
SHARON MARGUS
}

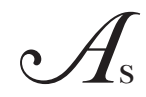

one of literature's most assiduous and complacent manufacturers of marriage plots, Anthony Trollope seems a perverse choice for inclusion in a discussion of lesbians and Victorian literary aesthetics, plausible only as a figure of that conjunction's implausibility. We know the routine: marriage is the enemy of lesbian desire, and realist novels can represent passion between women only as a subversion of the natural, social, and aesthetic order upheld by marriage. As invisible outlaws, lesbians generate an antiaesthetic that disrupts narrative form or lies outside realist form altogether. ${ }^{1}$ In her Intimate Friends Martha Vicinus has shown, however, that many Victorian women whose primary partners

Nineteenth-Century Literature, Vol. 6o, No. 3, pp. 291-325. ISSN: 0891-9356, online ISSN: 10678352 . ( 2005 by The Regents of the University of California. All rights reserved. Please direct all requests for permission to photocopy or reproduce article content through the University of California Press's Rights and Permissions website, at http://www.ucpress.edu/journals/rights.htm.

1 See Terry Castle, The Apparitional Lesbian: Female Homosexuality and Modern Culture (New York: Columbia Univ. Press, 1993); Marilyn R. Farwell, Heterosexual Plots and Lesbian Narratives (New York: New York Univ. Press, 1996); and Martha Vicinus, Intimate Friends: Women Who Loved Women, I778-1928 (Chicago: Univ. of Chicago Press, 2004). In my essay "Comparative Sapphism," I show that when Victorians did equate lesbianism with the monstrous and the unnatural, they also associated it with realism, an aesthetic many critics held in suspicion (see Sharon Marcus, "Comparative Sapphism," in The Literary Channel: The Inter-National Invention of the Novel, ed. Margaret Cohen and Carolyn Dever [Princeton: Princeton Univ. Press, 2002], pp. 25 $5^{1-85}$ ). 
were other women described their relationships as marriages. Vicinus dismisses women's marital "metaphors" as private fictions that could not compensate for the painful reality of being denied the privileges accorded to legally married couples, but her study presents evidence of acceptance that belies her paradigm of deviance. ${ }^{2}$

Women who were in "female marriages" were not the only ones to use the term, which was a nineteenth-century locution that circulated in conversation at respectable gatherings, not only as private code between lovers. Writing to her sister in 1852 , Elizabeth Barrett Browning reported that the wife of an English journalist had matter-of-factly used the phrase "female marriage" to describe the relationship between Charlotte Cushman and Matilda Hays. ${ }^{3}$ A woman legally married to a man casually referring to two women as married to each other: the scene underscores the uncharted realities embedded in metaphors, and it cautions us against being overly literal in how we understand the social and aesthetic forms taken by Victorian marriage.

In an era when marriage laws underwent radical changes, marital status was defined not by the law alone, but also by social recognition. The use of the term "female marriage" within Barrett Browning's circle suggests that far from being fictitious or faulty copies of a heterosexual norm, the marital metaphors applied to female couples were performatives whose utterance

\footnotetext{
2 Vicinus writes: "Like all metaphors, this one [husband and wife] failed when subjected to literal interpretation" (Intimate Friends, p. xxvii).

${ }^{3}$ Elizabeth Barrett Browning wrote to her sister Arabella in 1852 about meeting Matilda Hays and Charlotte Cushman: "I understand that she \& Miss Hayes [sic] have made vows of celibacy \& of eternal attachment to each other - they live together, dress alike ... it is a female marriage. I happened to say, 'Well, I never heard of such a thing before.' 'Haven't you,?' said Mrs Corkrane, . . . 'oh, it is by no means uncommon'” (Elizabeth Barrett Browning, letter to Arabella Barrett, 22 October 1852, cited in Robert Browning, Dearest Isa: Robert Browning's Letters to Isabella Blagden, ed. Edward C. McAleer [Austin: Univ. of Texas Press, 1951], p. 27, n. 12). My attention was drawn to this quotation by its partial citation in Lisa Merrill, When Romeo Was a Woman: Charlotte Cushman and Her Circle of Female Spectators (Ann Arbor: Univ. of Michigan Press, 1999), p. 16o. I discuss this letter in more detail in my essay "The Queerness of Victorian Marriage Reform," in Exploring Women's Studies: Looking Forward, Looking Back, ed. Carol Berkin, Judith L. Pinch, and Carole S. Appel (Upper Saddle River, N.J.: Pearson Prentice Hall, 2006), pp. 87-107.
} 
produced the relationship they described. ${ }^{4}$ Networks of acquaintances, friends, relatives, and colleagues conferred marital status on couples who could not marry under the law but whose relationships exhibited marital features such as cohabitation, financial interdependence, physical intimacy, and agreements about fidelity.

Scholarship has focused on how lesbians either inspired outrage or were overlooked entirely, on how women in samesex relationships were perceived as either unspeakably improper or utterly asexual, yet an unexplored world lies between these extremes. Acceptance of female couples was not necessarily premised on a willful ignorance about the sexual nature of their relationships. Because marriage existed in order to reconcile sexual desire and propriety, to identify a couple as married simultaneously named the bond as sexual and affirmed its respectability. To describe two women as united in a female marriage, therefore, was to acknowledge the legitimate sexuality of their relationship while according it the privacy that was one of the privileges of wedlock.

Even Anthony Trollope knew women in female marriages. His correspondence documents his cordial interactions with Frances Power Cobbe, Rhoda Broughton, Isa Blagden, Amelia Edwards, and Emily Faithfull. ${ }^{5}$ More in line with our familiar vision of Trollope as conservative is his aggravation with his

\footnotetext{
${ }^{4}$ Judith Butler has influentially used the notion of the performative to question the priority of heterosexuality over homosexuality and to explain how subjects defined by their deviation from a norm act to redefine the norm. See Judith Butler, Gender Trouble: Feminism and the Subversion of Identity (New York and London: Routledge, 199o); Butler, Antigone's Claim: Kinship between Life and Death (New York: Columbia Univ. Press, 200o); and Butler, "Is Kinship Always Already Heterosexual?" differences, 13, no. 1 (2002), 1444. On the ways that a nineteenth-century French novelist imagined a place within the law for relationships defined as outside it, see Michael Lucey, The Misfit of the Family: Balzac and the Social Forms of Sexuality (Durham, N.C.: Duke Univ. Press, 2003).

${ }_{5}^{5}$ On Trollope and Cobbe, see Anthony Trollope, letter to Frances Power Cobbe, 18 November 1866, in The Letters of Anthony Trollope, ed. N. John Hall, with the assistance of Nina Burgis, 2 vols. (Stanford: Stanford Univ. Press, 1983), I, 359 (hereafter Letters). On Trollope and Blagden, see Anthony Trollope, letter to Isa Blagden, 5 August 1862, in Letters, I, 19o; and Trollope, letter to Kate Field, 23 August 1862, in Letters, I, 191. On Trollope and Broughton, see Anthony Trollope, letter to Rhoda Broughton, 28 June 1868, in Letters, I, 434. On Trollope and Edwards, see Anthony
} 
friend Kate Field, whom he hectored to "go \& marry a husband," even as he helped her pursue a career as a writer. ${ }^{6}$ In his 23 August 1862 letter, Trollope wrote to Field that he did not "at all understand how [she was] living, where-with whomor on what terms" (Letters, I, 192) - registering a confusion that would last for much of their friendship. Yet the novel that he began writing a year later, Can You Forgive Her? (1864-65), suggests that he did understand that some women without husbands did not reject marriage altogether but instead chose a variation on it.

Trollope wrote Can You Forgive Her? in the wake of 1857 legislation that established England's first civil divorce court and spawned heated public debate about the meaning of marriage. Margaret F. King has shown that the novel's cyclical, halting marriage plot registers its author's anxieties about feminist attempts to reform marriage, and Kathy Alexis Psomiades has argued that Trollope, along with Victorian anthropologists, equated marriage with heterosexual exchange in order to counteract the erosion of gender difference in a capitalist economy that relied on women's economic agency. ${ }^{7}$ The presence of female marriage both in the feminist debates about marriage and in Trollope's novel has gone undetected, however, because of the assumption that same-sex relationships and marriage have until quite recently been mutually exclusive. Can You Forgive Her? exhibits some agitation about female marriage, but not because Trollope

Trollope, letter to Amelia Edwards, 26 September 1868, in Letters, I, 448; and Trollope, letter to Edwards, 20 July 1869 , in Letters, I, 476.

${ }^{6}$ Anthony Trollope, letter to Kate Field, 4 February 1862, in Letters, I, 175 . For an example of Trollope helping Field professionally while simultaneously admonishing her that women belonged at home, see Trollope, letter to Kate Field, 8 February 1877 , in Letters, II, 709 .

7 See King, "'Certain Learned Ladies': Trollope's Can You Forgive Her? and the Langham Place Circle," Victorian Literature and Culture, 21 (1993), 307-26; and Psomiades, "Heterosexual Exchange and Other Victorian Fictions: The Eustace Diamonds and Victorian Anthropology," Novel, 33 (1999), 93-1 18. Psomiades contends that Trollope and Victorian anthropologists only inadvertently opened up a way to think of sexuality as not exclusively heterosexual (see "Heterosexual Exchange," p. 95), while I argue that both had a more knowing awareness of the plasticity of sexuality and marriage. I provide a more detailed discussion of the anthropological framework of Victorian debates about marriage in my "The Queerness of Victorian Marriage Reform." 
equated any and every kind of love between women with subversion. Like most middle-class Victorians, Trollope valued intimacy between women as a component of normative femininity and hence as a basis for marriage. Female marriage perturbed Trollope because of its links to a troubling innovation in marriage between men and women - the feminist reform of marriage into a dissoluble and egalitarian contract.

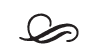

Victorian feminists argued that marriage should be a contract between autonomous equals who could dissolve their agreement by mutual consent, and they obtained a great deal of publicity for their vision of marriages based on similarity between spouses. John Stuart Mill argued that because equality and likeness were the foundations of true unions, marriage should emulate what "often happens between two friends of the same sex." ${ }^{8}$ Reformers linked their egalitarian vision to racialized narratives of civilization, progress, and modernity that condemned hierarchical marriage as primitive, savage, and barbaric. Upholders of tradition, conversely, argued that contract and divorce would degrade marriage by returning it to its origins in primitive promiscuity. The question of whether same-sex relations represented primitive promiscuity or modern egalitarianism also surfaced in the marriage debates, with several influential writers aligning same-sex unions with the advance of modern civilization.

The publicity surrounding the 1857 Matrimonial Causes Act made divorce, adultery, bigamy, and cross-dressing popular literary topics. ${ }^{9}$ Despite his reputation as a purveyor of anodyne fiction, Trollope explored those controversial issues in the early 1860 , just before he began Can You Forgive Her?. George Smith, of Smith, Elder, and Co., refused to publish two stories that Trollope submitted in 1860 , describing them as unfit for a

${ }^{8}$ John Stuart Mill, The Subjection of Women (1869), in his Essays on Sex Equality, ed. Alice S. Rossi (Chicago: Univ. of Chicago Press, 1970), p. 233.

9 See Barbara Leckie, Culture and Adultery: The Novel, the Newspaper, and the Law, I857-I914 (Philadelphia: Univ. of Pennsylvania Press, 1999). 
family magazine. Trollope's "The Banks of the Jordan" described a man attracted to a male travel companion who turns out to be a cross-dressed woman, and his "Mrs General Talboys" portrayed English expatriates in Italy who assert that the marriage tie is "by no means necessarily binding" and divorce no longer "the privilege of the dissolute rich." ${ }^{10}$ After Trollope succeeded in placing the stories elsewhere, readers complained about their risqué subject matter. ${ }^{11}$

Trollope incurred nothing but gratitude, however, when he contributed two stories free of charge to feminist Emily Faithfull, whose Victoria Press produced anthologies designed to showcase women's work as compositors and illustrators. ${ }^{12}$ Trollope never hid how much he relished receiving payment for his work, and his decision to donate fiction to an overtly feminist publication complicates the anti-feminist stances that he often took in his writing and lectures. In content as well as venue, the stories that Trollope gave Faithfull suggest his sympathy with women's desires for mobility and independence. "The Journey to Panama" (1861), which appeared in Faithfull's Victoria Regia, describes a young woman who decides not to marry after an inheritance leaves her financially independent. "Miss Ophelia Gledd" (1863), Trollope's contribution to Faithfull's second compendium, A Welcome, portrays a self-willed woman who does eventually marry but whom Trollope modeled on his unmarried friend Kate Field. ${ }^{13}$

10 See Anthony Trollope, "Mrs General Talboys" (1861), in his Early Short Stories, ed. John Sutherland (New York: Oxford Univ. Press, 1994), pp. 211 , 220.

11 On the publisher's and readers' reactions to these stories, see Sutherland, "Introduction," in Trollope, Early Short Stories, pp. xiii, xvii.

12 See Anthony Trollope, "The Journey to Panama," in The Victoria Regia: A Volume of Original Contributions in Poetry and Prose, ed. Adelaide A. Procter (London: Printed and Published by Emily Faithfull and Co., Victoria Press for the Employment of Women, 1861 ), pp. 187-214; and Anthony Trollope, "Miss Ophelia Gledd," in A Welcome: Original Contributions in Poetry and Prose Addressed To Alexandra, Princess of Wales (London: Printed and Published by Emily Faithfull and Co., Victoria Press for the Employment of Women, 1863), pp. 239-83. On Trollope's friendship with Faithfull, see King, "Certain Learned Ladies," p. 311 . King discusses how Faithfull and other feminists sought to provide women with alternatives to heterosexual marriage, but she does not elaborate on how Faithfull herself chose female marriage as one such alternative.

${ }^{13}$ N. John Hall notes the resemblance between Kate Field and Ophelia Gledd (see Hall, Trollope: A Biography [Oxford: Clarendon Press, 1991], p. 340n). 
Trollope's social and professional involvement with Kate Field and Emily Faithfull speaks volumes about his awareness of female marriage and erotic relationships between women. Kate Field has traditionally been the closest thing in Trollope studies to a study in scarlet, the only hint that Trollope was ever less than completely faithful to his wife. ${ }^{14}$ But to examine Field only through the lens of Trollope's romantic fantasies about her is to overlook the more lavender shades that tinged her life. Field and Trollope were linked by a social network that united samesex couples, legally married opposite-sex couples, and unmarried men and women whose sexual interests varied. They first met in 1860 when Trollope was visiting his mother and brother, who belonged to the same expatriate circle as Field-an Anglo-American network that included Walter Savage Landor, the Brownings, and Mary Somerville as well as women in female marriages and having affairs with women, such as Charlotte Cushman, Emma Stebbins, Isa Blagden, Harriet Hosmer, Frances Power Cobbe, and Mary Lloyd. ${ }^{15}$

A favorite of both Brownings, Field was also a childhood friend of Emma Crow, the young woman with whom Cushman was having a secret affair while living with Emma Stebbins in a relationship consistently described as a marriage. ${ }^{16}$ Field had gone to Italy to recover from unrequited love for a married aunt, and thus arrived primed to appreciate the same-sex relationships she encountered there. While in Florence, Field flirtatiously referred to her hostess Isa Blagden as "Hubby" and

14 In his edition of Trollope's letters, N. John Hall refers to Trollope's "longstanding romantic attachment to Kate Field" (see Letters, I, 126, n. 7). Sutherland refers to Field as "the young Boston feminist with whom Trollope had a long platonic affair" (see Sutherland, "Introduction," in Early Short Stories, p. xxiii).

15 For the best accounts of Cushman's circle, see Merrill, When Romeo Was a Woman; and Vicinus, Intimate Friends, pp. 31-55. Both authors, however, overstate the extent to which women like Cushman and Hosmer formed a separate community. See also Julia Markus, Across an Untried Sea: Discovering Lives Hidden in the Shadow of Convention and Time (New York: Alfred A. Knopf, 200o).

16 On Cushman's marital language, see Merrill, When Romeo Was a Woman, pp. 189-

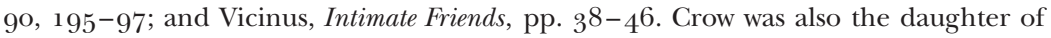
Harriet Hosmer's patron, Wayman Crow, and the sister of Hosmer's childhood friend Cornelia Crow Carr. In his 4 February 1862 letter to Kate Field, Trollope wrote that he had received news of her from Emma Crow (see Letters, I, 174). 
exchanged presents with Frances Power Cobbe. ${ }^{17}$ Having previously met Charlotte Cushman in the United States through her aunt, Field slyly saluted the actress's erotic and quasi-marital relationship with Emma Stebbins by addressing Cushman as "Beloved Romeo" and referring to Stebbins as "Juliet."18

Field and Trollope maintained regular contact after meeting in 1860 , but their relationship was always strained by Field's allegiance to the female independence and female marriage of which she had seen so many examples in Italy. Trollope was not universally hostile to women in female marriages, and was even on friendly terms with many of them. He helped Isa Blagden contact British publishers, knew Frances Power Cobbe, and sought out the acquaintance of Amelia Edwards. He contributed to Victoria Regia along with Matilda Hays, who had been Charlotte Cushman's partner in the 185 os and then formed a long relationship with Theodosia, Lady Monson. ${ }^{19}$ In Field's case, however, Trollope was less tolerant, and his platonic romance with her consisted mostly of berating her for not marrying a man.

Field did eventually settle down - with another woman. Trollope died the year that Field met the woman who became her partner, so we cannot know how he would have responded to learning that his friend had finally heeded his advice, after a fashion. We do know that the Victorian middle class defined marriage in terms of shared households, financial support,

17 On Field's term for Blagden, see Merrill, When Romeo Was a Woman, p. 195. On Cobbe's present, see Lilian Whiting, Kate Field: A Record (Boston: Little, Brown, 19oo), p. 102.

18 On Field's terms for Cushman and Stebbins, see Merrill, When Romeo Was a Woman, p. 195. On Field's first meeting with Cushman, see Whiting, Kate Field, p. 47. On Field's love for her aunt, see Kate Field, letter to Cordelia Riddle Sanford, February 186o, in Kate Field: Selected Letters, ed. Carolyn J. Moss (Carbondale and Edwardsville: Southern Illinois Univ. Press, 1996), p. 17; and Whiting, Kate Field, pp. 46-47, 73-75. On Field's connections with the Cushman circle in Rome, see Merrill, When Romeo Was a Woman, p. 195 .

19 On Hays's relationship with Lady Monson, see Lee Holcombe, Wives and Property: Reform of the Married Women's Property Law in Nineteenth-Century England (Toronto: Univ. of Toronto Press, 1983), p. 85; and Nancy Fix Anderson, Woman against Women in Victorian England: A Life of Eliza Lynn Linton (Bloomington and Indianapolis: Indiana Univ. Press, 1987), p. 63. Lady Monson supported a women's reading room in Langham Place, a project in which Emily Faithfull also participated (see Frederick Dolman, "Afternoon Tea with Miss Emily Faithfull," The Young Woman, 3 [1894-95], 318-19). 
bequests of wealth and property, the care of the body in life and death, and vows and practices of exclusive commitment and unique spiritual communion. By those criteria Field clearly had a spouse, for wherever we turn in the record of her later life we find one woman. The woman to whom Field entrusted her body for burial was Lilian Whiting, who also inherited Field's letters, journals, and possessions; wrote a loving biographical tribute to Field; penned a spiritualist memoir about her encounters with Field's ghost; and was buried next to Field in Mount Auburn Cemetery. ${ }^{20}$ Whiting based a biography, Kate Field: A Record (1900), on the papers that she inherited after Field's death in 1896 and on the "private letter[s]" that Field had sent her daily whenever they were apart. ${ }^{21}$ Kate Field adheres to nineteenth-century biographical conventions that encouraged authors to stay invisible even when writing about family members and spouses whom they knew intimately. Whiting rarely uses the first person, and she refers to herself only as "the biographer." Yet she also tells the reader, almost in passing, that "the biographer" and Kate Field lived together whenever Field was not traveling and that Field wanted to support Whiting financially. Through frequent, casual references to what Field "always" did or felt, Whiting subtly conveys intimacy with her subject, just as she communicates their erotic relationship by naming her own "memory" as the source of a sensuous rhapsody about Field's beauty. ${ }^{22}$

${ }^{20}$ Blanche Cox Clegg's entry on Lilian Whiting in American National Biography refers to Whiting and Field as "close friends" (see American National Biography, ed. John A. Garraty and Mark C. Carnes, 24 vols. [New York: Oxford Univ. Press, 1999], XXIII, 268). Jessie Rittenhouse's biography of Whiting refers to Kate Field as the woman "for whom Miss Whiting cherished the most tender and consecrated friendship" (see Rittenhouse, Lilian Whiting: Journalist, Essayist, Critic, and Poet: A Sketch [no date or publisher], p. 7).

21 Whiting mourned Field in print for some years after her death. In 1895 , a year before Field died, Whiting dedicated a volume of poems to her, From Dreamland Sent (Boston: Roberts Brothers, 1895), which included many individual poems specifically addressed to Field. Whiting described her experiences of communing with Field's spirit and wrote of Field as the "magnetic centre" of her life (see Whiting, After Her Death: The Story of a Summer [Boston: Roberts Brothers, 1898], p. 25). On the link between lesbian eroticism and spiritualism, see Terry Castle, "Marie Antoinette Obsession," in The Apparitional Lesbian, pp. 107-49.

${ }^{22}$ For examples of Whiting's use of "always" in relation to Field, see Kate Field, pp. 32, 281, 552, 572 . For Whiting's memories of Field's beauty, see Kate Field, p. $43^{2}$. 
Although Trollope claimed to find Field's life incomprehensible, their shared acquaintance with women like Cushman, Cobbe, Hosmer, and Faithfull shows that he had a context for understanding Field's choices. His acquaintance with both Field and Faithfull influenced his characterization of Field's namesake Kate Vavasor in Can You Forgive Her? ${ }^{23}$ When Trollope contributed "Miss Ophelia Gledd," the story based on Field, to Faithfull's anthology A Welcome, he did so "as a kind of friendly lark, done chiefly for the sake of Emily Faithfull herself." ${ }^{24}$ He also showed his commitment to Faithfull at a time (the early months of 1863) when rumors had begun to swirl about her relationship with Helen Codrington. Emily Faithfull had lived with Helen Codrington and her husband for several years in the $185 \mathrm{os}$; when Admiral Codrington sued his wife for divorce, Faithfull was a crucial witness in a trial that publicized her overly intimate relationship with a woman accused of adultery with men. ${ }^{25}$ The actual trial did not begin until July 1864 , but Admiral Codrington filed divorce papers in 1863. By the time Trollope began Can You Forgive Her? that same year, he would have probably heard the rumors that had already caused a few of Faithfull's feminist friends to sever personal and professional contact with her. ${ }^{26}$

While some feminists were anxious lest sexual scandal taint their political endeavors, the less-vulnerable Trollope contin-

${ }^{23}$ Hall notes that Can You Forgive Her? "owes something to Trollope's argument with Kate Field” (Trollope: A Biography, p. 267). Field and Faithfull were acquainted with each other: the Kate Field collection that Lilian Whiting donated to the Boston Public Library contains letters from Emily Faithfull to Kate Field from 1878 discussing a benefit Kate Field was organizing, whose performers included Faithfull's lover at the time, Kate Pattison. See Kate Field Collection, Boston Public Library, Ms. KF 1081-1087.

24 See Hall, Trollope: A Biography, p. 340n.

${ }_{25}$ On Faithfull's role in the Codrington divorce trial, see Vicinus, Intimate Friends, pp. 69-75. Faithfull's decision to testify against Helen Codrington saved her reputation, even as she continued to have female lovers. She maintained the Victoria Press and was later awarded a Civil List pension for her services on behalf of the education and employment of women. On Faithfull's life, see James S. Stone, Emily Faithfull: Victorian Champion of Women's Rights (Toronto: P. D. Meany Publishers, 1994).

${ }^{26}$ Stone notes that Adelaide Procter ended her friendship with Faithfull in 1862 and that Bessie Rayner Parkes canceled Faithfull's contract to publish the English Woman's Journal in December 1863 . Stone also notes that some of Faithfull's other feminist friends remained loyal, including Matilda Hays, Cushman's former lover. See Stone, Emily Faithfull, pp. 16-18. 
ued to socialize with Faithfull, spending time with her in June 1863 and in 1864. Faithfull visited Trollope's home at Waltham Cross on 16 February 1864, and she lunched with Trollope and his wife in Greenwich on 15 June 1864 , only six weeks before giving evidence in the Codrington trial. ${ }^{27}$ On both occasions, Faithfull brought along Emilie Wilson, daughter of a member of Parliament and Faithfull's intimate since 1 862. ${ }^{28}$

In November 1863, Admiral Codrington first filed the divorce papers attesting that his adulterous wife Helen had shared a bed with Emily Faithfull for years. In that same month, Anthony Trollope was at work on the chapter that lies at the literal and figurative center of Can You Forgive Her?, "Among the Fells." That chapter provides a key to the link that Trollope made between Emily Faithfull and Kate Field, for in it a character named Kate Vavasor - who like her namesake Kate Field never marries a man-proposes marriage to her cousin Alice.

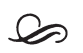

Trollope's novels seem to leave little room for female marriage, crowded as they are with the multiple male suitors who exemplify his trademark variation on the marriage plot. Rather than focus on the obstacles to courtship between one man and one woman, Trollope's novels unfold as dilemmas of choice. Amid an abundance of proposals, a Trollope heroine must choose between two or more suitors in order to arrive at a decision final in every sense, timed to coincide with the novel's end and pronounced with the permanence of a marriage vow. The central heroine of Can You Forgive Her? must also choose between two suitors, but the novel undoes the certainties of the marriage plot by beginning where most Trollope novels end, with her engagement to be married. The narrator emphasizes that his starting point inverts conventional novel form when he

27 On the June 1863 visit, see Anthony Trollope, letter to W. H. Russell, 29 May 1863, in Letters, I, 220. For the 1864 dates, see Martha Westwater, The Wilson Sisters: A Biographical Study of Upper Middle-Class Victorian Life (Athens: Ohio Univ. Press, 1984), p. 117 .

${ }^{28}$ The details of Faithfull's relationship with Wilson are documented in the diaries of Wilson's sister Eliza, excerpted in Westwater, The Wilson Sisters. 
concludes his first chapter with a dramatic declaration about his heroine Alice Vavasor: "And now for my fact. At the time of which I am writing she was already engaged to be married." 29 Readers are left wondering where Alice could possibly go from there, and reviewers were predictably impatient with a plot that recounts how Alice repeatedly breaks and remakes engagements with two different men. The suitor to whom she is engaged at the novel's start (and whom she ultimately marries) is the upright John Grey; the suitor to whom she had been engaged in the past, and to whom she gets engaged again after breaking with John, is her shifty cousin, George Vavasor. Each man also has a female counterpart who advocates on his behalf: Alice's cousin Glencora favors John Grey, while George's courtship of Alice is almost entirely conducted by his sister Kate Vavasor, who is also Alice's closest friend.

Margaret F. King has argued that Can You Forgive Her? chastises its heroine for her aspirations to be something other than a man's wife, but Alice does not simply resist marriage per se. Rather, she rejects one kind of marriage in order to embrace another-resisting John, an indomitable superior who insists on the permanence of marriage promises, but embracing George, who allows Alice to define marriage as dissoluble, egalitarian, and contractual. Alice's engagement to George makes marriage promises dissoluble because it depends on Alice's decision to end her prior engagement to John. Promises to marry did not customarily have the same weight as promises of marriage, but the novel equates broken engagements with divorce, as characters and the narrator repeatedly assert that engagements must not be broken. Alice's relatives tell her that "a young lady has no right to change her mind" after "accept[ing] a gentleman" (p. 219), and when Alice tells John that she wants to end their engagement, he insists that in effect they are already married: "You are my wife, my own, my dearest, my chosen one" (p. 147). To treat engagement as tantamount to marriage is to make breaking an engagement equivalent to divorce.

${ }^{29}$ Anthony Trollope, Can You Forgive Her?, ed. Stephen Wall (London: Penguin Classics, 1986), p. 45 . Further references are to this edition and appear in the body of the text. 
Alice also initially sees in George the possibility of an egalitarian union that bypasses sexual difference, since she feels for him "none of the love of a woman" (p. 490) and is attracted to him because he indulges her love of politics and London, a place that she identifies with her masculine aspirations, when she says: "Were I a man, no earthly consideration should induce me to live elsewhere" (p. 61). Alice and George make their engagement contractual by conducting much of their marital business in writing, as a series of negotiations that lead to painstakingly documented agreements about money. George's marriage proposal is a business proposition that arrives in the form of a letter asking Alice to fund his political career. His mercenary interest in Alice's independent income harmonizes with her desire to conceive of their engagement as a contractual agreement between equals. Alice wants George to use her money because, like a man and a speculator, she wants to "run much risk" (p. 350). Her written reply treats George's epistolary proposal as a step in a negotiation: "Dear George, if you will accept me under such circumstances, I will be your wife” (p. 355). In an act that the narrator calls an "offer," George later tells Alice that she can "retract" her letter accepting him (p. 378). Alice's engagement to George becomes a literal contract when she signs bills of exchange for him. He presents the details in a letter to her, making her marital pledge a monetary one: "four bills, each of five hundred pounds, drawn at fourteen days' date" (p. 628). Instructing Alice on how to sign bills, George explains that her "name must come under the word 'accepted" (pp. 628-20) - thus transforming a word with marital connotations into a business term. When George explains in the letter, delivered by a moneylender, that it is "more than ever incumbent on you that you should be true to your pledge to me" (p. 628), he means her pledge to lend him money, not to marry him.

Marriage to George also entails a union between Alice and the woman who mediates his suit. Midway through Can You Forgive Her?, Alice refuses to kiss George after having accepted his proposal, and the narrator asks: "Of what marriage had she thought, when she was writing that letter back to George Vavasor?" (p. 397). The question is not rhetorical; the narrator 
answers it, explaining that Alice had imagined marriage to George as that of "one friend" with another: "His disgrace should be her disgrace; - his glory her glory;- - his pursuits her pursuits. Was not that the marriage to which she had consented?" (p. 398). Alice's reported thoughts equate marriage to George with the biblical story of Ruth and Naomi, whose balanced cadences she echoes, and the allusion to a popular motif of female friendship suggests what the novel elsewhere confirms: that the marriage that Alice thought of when accepting George was a marriage to his female intercessor. ${ }^{30}$

To associate marriage to a man with a bond between women is not a mere delusion in a narrative that repeatedly links a woman's male suitor to a female one. Although in other respects George is hyperbolically masculine, the anatomical part he offers Alice in marriage - his hand - is remarkable for having "a surface smooth as a woman's" (p. 177), and the hand that orchestrates Alice's engagement to George literally belongs to a woman-Alice's cousin and George's sister Kate. Critics have tended to explain Kate's zeal in promoting Alice's marriage to George as a displacement of incestuous desire for her brother. ${ }^{31}$ The search for hidden heterosexual meanings, however, has neglected the homoerotic ones on the story's surface: the bond that Kate fosters between Alice and George is embedded in the deeper one between herself and Alice. Kate does not desire her brother so much as identify with him so deeply that, in her eyes, for Alice to accept George is also to accept Kate. Kate works harder to seduce Alice than George himself does, and George only proposes to Alice because, literally and figuratively, Kate makes "room for him between herself and Alice" (p. 91). When George shows little eagerness to court Alice, Kate complains: "I'm moving heaven and earth to bring

${ }^{30}$ On Ruth and Naomi as icons of female friendship, see Deborah Cherry, Painting Women: Victorian Women Artists (London and New York: Routledge, 1993), p. 51. On the frequent depiction of the two women in illustrated Victorian family Bibles, see Mary Wilson Carpenter, Imperial Bibles, Domestic Bodies: Women, Sexuality, and Religion in the Victorian Market (Athens: Ohio Univ. Press, 2003), p. $5^{8 .}$

31 See James R. Kincaid, The Novels of Anthony Trollope (Oxford: Clarendon Press, 1977), p. 186; and Kate Flint, "Introduction: Trollope and Sexual Politics," in Anthony Trollope, Can You Forgive Her?, ed. Andrew Swarbrick (New York: Oxford Univ. Press, 1982 ), p. xxiv. 
you two together" (p. 94). She later berates herself for having separated Alice from John Grey in order to "allure her into the arms of" George Vavasor (p. 6oo). The narrative even suggests that Kate and George, who have the same kinship relation to Alice, occupy an equivalent place in her marital projects. When Alice tells herself that "after all she might as well marry her cousin" (p. 397) or remembers herself accepting "her cousin's offer" (p. 373), the neuter kinship term suggests that Kate is as much her prospective spouse as George is.

If grammatical ambiguity suggests that the cousin who offers marriage could be female as well as male, then the novel's handling of the proposal scene, the formal climax of a marriage plot, leaves no doubt about who offers marriage to Alice. In "Among the Fells" (pp. 335-47), the chapter that Trollope wrote during the time when the Emily Faithfull scandal was revealing how closely a woman might become entangled in another woman's marriage, Alice spends Christmas with her grandfather, father, and Kate, and receives a letter from George proposing marriage. The previous chapter, written from George's point of view in London, depicts him composing a letter asking Alice to marry him and ends by rapidly projecting into the future: "And before the end of the week the answer came" (p. 335). The cliffhanger ending heightens the narrative stakes of the following chapter, which breaks with linear convention by moving back in time in order to reveal the outcome that the narrator has announced but not revealed.

"Among the Fells" presents marriage between a man and a woman as a contractual agreement negotiated in writing, and female marriage as a passionate encounter between embodied subjects. The manifest resolution of the mystery is that Alice accepts George's epistolary proposal, but equally manifest is George's absence from the scene of her assent and Kate's presence as a powerful surrogate suitor. It is Kate who incarnates courtship, as she and Alice walk together in an expressionist landscape dominated by trinities, figures of three that symbolize how the engagement between a man and a woman creates a triangle that also includes a female couple. Kate's and Alice's destination when they seek a spot to discuss George's letter is a lake "not above three miles long," carved deep into a rock in 
"the shape of the figure of 3 " (p. 344). Both the reference to the figure of three and the typographically startling presence of the individual numeral " 3 ," rather than the word "three" made up of several letters, express how multiple components coalesce into a single unit. As a shape, the numeral 3 is made up of two equal parts, a form that mirrors the contractual couple that Alice hopes to form with George and the actual couple that she forms with Kate. When the narrator strains usage to describe the lake as "embosomed" in the mountains (p. 344), he draws our attention to the femininity of the two identical parts that comprise the numeral 3 , for his metaphor directs the reader to see how the numeral's form resembles the outline of a pair of breasts.

The chapter's content develops the setting's evocation of female coupling. By giving George's letter to Kate to read, Alice asks her to materialize his proposal; Kate avidly sets herself to that task, demanding not that Alice promise to accept George but that she say yes immediately-to Kate. Immediately after reading George's letter, Kate uses the words and gestures of a Victorian suitor demanding the hand of the woman he loves: "'Oh, Alice, may I hope? Alice, my own Alice, my darling, my friend! Say that it shall be so.' And Kate knelt at her friend's feet upon the heather, and looked up into her face with eyes full of tears" (p. 345). Just before kneeling at Alice's feet, Kate herself emphasizes the marital meaning of that posture when she conjectures that one of their aunt's eager suitors similarly "kneels ... on every occasion ... and repeats his offer ... twice a week" (p. 340). When Kate imagines Alice accepting George, she longs to be in his place, saying of "the love-sweet words" that she imagines Alice will use: "I know how sweet they will be. Oh, heavens! how I envy him!” (p. 347). George's desire to marry Alice is so much Kate's desire as well that it becomes difficult to sustain any distinction between them. When Kate reads George's letter, she exults, asking Alice: "is it not a letter of which if you were his brother you would feel proud if another girl had shown it to you?" (p. 345). The choice of sibling term is striking: although she is George's sister, Kate asks Alice to imagine her as a man - as George's brother, or, since George is her brother, as George himself. 
As a woman courting another woman on a man's behalf, Kate goes far beyond the role of intermediary. She kisses the spot where she has read his letter (p. 345); she insists to Alice, "I know you will not refuse him; but make me happy by saying so with your own lips" (p. 346); and she requests of Alice, "You will not answer him without speaking to me first?" (p. 347). Like all of Alice's suitors, Kate seeks to quicken the pace of Alice's response, and Alice, as she does with all of her suitors, complains that she does not want to answer quickly: "I knew well how it would be, and that you would strive to hurry me into an immediate promise" (p. 346). Like any canny aspiring husband, Kate responds by saying that she accepts delay but does not desire it: "No, Alice, I will not hurry you. . . . But you cannot be surprised that I should be very eager. Has it not been the longing of all my life? Have I not passed my time plotting and planning and thinking of it till I have had time to think of nothing else?" (p. 346). Kate repeats throughout the chapter not only that she is vicariously happy for George and Alice, but also that their marriage realizes her own desires: "can you be surprised that I am wild with joy when I begin to see that everything will be as I wish; - for it will be as I wish, Alice" (p. 346).

The novel invests one woman's marriage proposal to another with an ease noticeably absent from its many instances of impeded courtship between women and men. Alice responds to Kate more readily than to either of her male suitors, acknowledging that Kate's enthusiasm makes it "almost impossible for her now to say that her answer to George must be a refusal" (p. 345, emphasis added). When Alice writes her explicit acceptance to George a week later, she informs Kate indirectly, in the way a modest woman would assent to a proposal. Taking hold of Alice's arm, Kate asks what she has written to George, and Alice replies obliquely: "I have kept my promise" (p. 348). Kate then claims Alice with a performative utterance and gesture that fixes the meaning of Alice's response: “My sister, my own sister,' said Kate. And then, as Alice met her embrace, there was no longer any doubt as to the nature of the reply" (p. 348). Kate's reply mimics the ability of the marriage ceremony to create new relationships through proprietary renaming ("my own sister") and expressive touch (the embrace), and 
Alice affirms Kate's role as suitor when she asks Kate to disclose the news to Alice's father (p. 351).

Just as the woman proposing marriage to another woman on a man's behalf does so as an extension of her own desires, so too the woman who accepts her proposal announces an independent interest in her female suitor. Alice avows at several junctures that her love for Kate is independent of what she feels — or does not feel-for George. She responds to George's written marriage proposal by warning him: "Kate, who is here, talks to me of passionate love. There is no such passion left to me;-nor, as I think, to you either" (p. 355). If there is no passion left to Alice, it is because Kate has left her side, for when she prepares to write John of her engagement to George, she wishes she had done so when "Kate had been near her, and she had been comforted by Kate's affectionate happiness. . . . The atmosphere of the fells had buoyed her up" (p. 386). Throughout a novel in which she is spectacularly indecisive, Alice retains her fantasy of pledging herself to Kate alone, without the mediation of marriage to a man identified with Kate. Early on, Alice says: "I hope that Kate will always live with me"; and "I don't think she will ever find that I shall separate myself from her" (pp. 174, 175). She recalls that wish hundreds of pages later, after she breaks her engagement with George: "I believe that everything has been done for the best. I am inclined to think that I can live alone, or perhaps with my cousin Kate, more happily than I could with any husband" (p. 716). The narrator has Alice "contemplate . . . a life of spinsterhood with her cousin Kate," an oxymoron that articulates Trollope's awareness that women who did not marry men were not necessarily solitary (p. 313). Even characters outside the female couple recognize the strength of Alice's love for Kate; Glencora Palliser teases Alice about her indifference to male suitors, playfully saying: "I wonder whether you ever did care for anybody in your life,-for him, or for that other one, or for anybody. For nobody, I believe;-except your cousin Kate" (p. 728$)$.

In the chapter "Among the Fells" one woman proposes to another as the ostensible representative of a male suitor, but in Can You Forgive Her? as a whole Trollope uses the value systems 
implicit in plot closure and narration to elevate the intimacy between female suitors above contractual marriage between a woman and a man. The novel ultimately eliminates the man who ostensibly united Kate and Alice, but his removal becomes an occasion to reaffirm the women's solidarity. The bond between Kate and Alice only becomes stronger after George's hold on the novel frays and he absconds to the United States under a false name. In "Among the Fells" Alice asks Kate to read a letter sent by George, but later in the novel Alice writes directly to Kate, who is the sole recipient of Alice's confidences about her last scene with George- "I must tell it to you, but I shall never repeat the story to any one else" (p. 569). Just as she had asked Kate to make her engagement with George, Alice in this letter asks her to break it: "I do not know whether he understands that everything must be over between us; but, if not, I must ask you to tell him so" (p. 571). The pride of place that Alice assigns to Kate in ending the engagement to George preserves the importance that Kate acquired in initiating it. Kate's role as Alice's only addressee underscores that the reader's knowledge of what happens in the heterosexual marriage plot depends on the communication between two women.

Can You Forgive Her? depicts the bond between women as impervious to the vagaries that destabilize relationships between men and women, which are limited by having only one permissible form: hierarchical marriage. By contrast, women have multiple forms of relationship at their disposal, including friendship, female marriage based on triangulation with a male suitor, and solidarity based on mutual rejection of a male suitor. Kate and Alice replace their reciprocal adoration of George with an equally shared revulsion from his violence after he threatens Alice and pushes Kate so hard that she falls and breaks her arm. After reading Alice's letter, Kate feels "repugnance" toward George (p. 591) and wonders if, like Alice, she will need to "abandon him altogether" and "divide herself from him" (p. 6oo). Even when both women sever their links to George, he continues to strengthen their union, now based on shared pain. Kate tells Alice: "Alice, dear! we have both suffered for him; you more than I, perhaps; but I, too, have given up everything for him" (p. 666). Shame isolates, but because Alice 
and Kate share their humiliating disillusionment in George with each other, even their shame unites rather than separates them. Alice writes to Kate that she fears her break with George will cause "a division between" the two women (p. 571), but Kate responds that even in George's absence their relationship will retain the sororal, superlative status that Kate claimed when Alice first accepted her proposal: "My own Alice,-_If you will let me, you shall be my sister, and be the nearest to me and the dearest" (p. 574).

As Can You Forgive Her? draws to a close, contractual marriage between a man and woman disappears, but the narrative preserves the conjugal connotations of the relationship between Kate and her "nearest ... and ... dearest." After breaking with George and before embarking on a European trip, Alice visits Kate at Vavasor Hall in a gesture that represents their ongoing pledge to each other. Although Alice's chief characteristic is her difficulty in keeping her word, she assents to "Kate's desire ... that Alice should come down to her for a while" (p. 602) because she is "resolved that she would keep her promise to Kate" (p. 653). In contrast to her engagements to John and George, which she strives to confine to print, Alice seeks direct contact with Kate: "After all that had passed she felt that she owed Kate some sympathy. ... there are things ... which can be spoken, but which cannot be written" (p. 653). The narrator later commends the women's loyalty by nominally describing them as a married couple, as he wraps up one plot and transitions to another: "Reader, let us wish a happy married life to Captain and Mrs Bellfield!" After a paragraph break, the narrator continues: "The day after the ceremony Alice Vavasor and Kate Vavasor started for Matching Priory" (p. 814). The women's destination is the estate where Alice will marry John Grey, but, far from implying that marriage requires Alice to relinquish her bond with Kate, the novel suggests that they remain wedded to each other. The reference to "Captain and Mrs Bellfield" underscores that a woman who marries shares her husband's name, and the phrase's placement immediately before the allusion to "Alice Vavasor and Kate Vavasor" reminds us that the female cousins, like a married couple, share a last name as well. The mention of the women's common surname is gratuitous at this point in the 
novel, but it creates a parallelism that aligns them with the newly minted married couple. At the same time, the phrase subtly distinguishes the female couple from the legally married one: "Captain and Mrs Bellfield" have only one surname between them, while "Alice Vavasor and Kate Vavasor" have individual surnames in common. The first phrase reminds us that legal marriage subsumes even the most powerful woman into her husband, while the second phrase highlights that the female couple consists of two linked, equal parts.

The place-name "Matching Priory," where Alice marries John Grey, reinforces the precedence of matches between husbands and wives, but Kate's presence at Alice's side represents the survival of the women's prior match. Why does the novel eliminate a male suitor but not the woman who proposed marriage for him? In a work fascinated with the punishments inflicted by the self and by others, Kate provides a spectacular instance of suffering for her misdeeds, when her brother breaks her arm because she refuses to lie on his behalf. One might conclude that Kate remains in the novel only so we can see her pay for her sins in chapter 56 , whose title, "Another Walk on the Fells," echoes and replaces "Among the Fells." It is tempting to read Kate as a gender outlaw punished for deviant desires: twice a bridesmaid but never a bride (pp. 683, 815), she is indifferent to masculine beauty (p. 66) and keenly appreciates women's attractions (p. 1o6). It would be reductive, however, to read the violence that Kate suffers as a simple narrative reprisal against an odd woman who rejects marriage and desires women. The novel shows Alice and Kate together long after portraying Kate's fall, and in its conclusion grants Kate the ultimate reward of Victorian fiction, a small independent fortune that enables her to avoid marriage permanently and in comfort.

The narrative punishes Kate not for proposing female marriage but for representing a man who offered to make marriage a contract. As a version of the female intimacy on which hierarchical marriage itself depends, female marriage is too closely allied to the novel's most valued conjugal form to be eliminated. The role that female romance plays in securing hierarchical marriage emerges most clearly in Alice's dealings with another cousin, Glencora Palliser. Miming marriage to 
Alice provides the crucial assistance that Glencora needs in order to stay with Plantagenet Palliser, the imperious husband whom relatives coerced her into marrying. On her first visit to Glencora at Matching Priory, Alice temporarily becomes the loving husband that Plantagenet is not, as the narrator describes: "Lady Glencora was now in the habit of having Alice with her in what she called the dressing-room every evening, and then they would sit till the small hours came upon them" (p. 286). And Alice offers Glencora the declarations of love that Plantagenet does not. "I love you with all my heart," Alice tells Glencora, who replies: "Some one's love I must have found,- - or I could not have remained here" (p. 288). Even after Glencora and Plantagenet strive to become closer, both still require Alice's presence to seal their bond. Plantagenet defers to Glencora by asking her to invite Alice to join them on a trip abroad, and Glencora begs Alice for her company: "Alice, I want you more than I ever wanted you before" (p. 715). The Pallisers' relationship stabilizes after Glencora becomes pregnant and gives birth to a boy, but even in the novel's last pages, we see the Palliser heir not with his mother and father, but with the two women (pp. 827-28).

Female intimacy in Can You Forgive Her? is thus no simple foe of conjugal happiness; indeed, in the case of Alice and Glencora, an eroticized attachment between women is a necessary lubricant for facilitating marriage between a woman and a man - and the novel thus finds room for Kate Vavasor. Insofar as realism strives to represent the world as it is, Trollope could not ignore the female marriages that he knew existed as recognized social facts. And insofar as realism seeks to represent the world in the image of its values, Trollope can only applaud the loyalty and affection that subtend Kate's proposal to Alicewhile at the same time condemning the contractual, egalitarian marriage that Kate promotes between George and Alice. Kate herself is no proponent of egalitarian marriage; Trollope does not depict female intimacy as consistently feminist, and Kate's passionate demands as a suitor are inimical to the tempered self-possession typical of contracts between equals. Kate, through her identification with George, does represent egalitarian marriage by proxy, however, and her punishment at his 
hands shows that her crime is his. To "get it in writing" is now shorthand for an immutable commitment, but Victorians steeped in debates about marriage and divorce contrasted revocable written contracts to irreversible vows. When George's attack leaves Kate's right arm "powerless" (p. 594) and makes "writing to Alice ... now out of the question" (p. 6oo), the reader discerns that Kate suffers for having helped to make marriage a contract that took written form. Kate is guilty not of loving another woman but of advocating the wrong kind of marriage to the wrong kind of man.

In Can You Forgive Her? Trollope gives narrative form to Victorian debates about marriage. George is initially the sign of contract's affinity with modernity and progress, but in "Another Walk on the Fells" he becomes an avatar of force whose hand no longer pens offers but instead exercises a "great violence" that undoes Kate's ability to write (p. 594). At the outset of Can You Forgive Her? George represents Alice's freedom to dissolve marriage promises as well as her feminist ambition and independence. By the novel's end he is living proof of the primitive violence that conservatives warned would result if divorce were to make marriage more like a contract.

Trollope and the Victorians associated contract with the feminist reform of marriage, but, over a century later, literary critics began to equate both contract and marriage with fixed constraints that consolidate hierarchies. In Adultery in the Novel Tony Tanner defines contract as the laws and distinctions that structure society, arguing that the novel stages a conflict between marriage as contract on the one hand and adultery as transgression and formlessness on the other hand. ${ }^{32}$ Tanner's ahistorical structuralist account of contract cannot explain why a novelist like Trollope aligned contract with a heroine's disruptive fantasies of equality and autonomy. Joseph Allen Boone, in a more historically nuanced study of the novel's dependence on

32 See Tony Tanner, Adultery in the Novel: Contract and Transgression (Baltimore: Johns Hopkins Univ. Press, 1979), pp. 6, 12, 13, 15 . 
marriage plots, underscores how nineteenth-century novels created a dialectic between a companionate, egalitarian, contractual ideal of marriage and an authoritarian model in which husbands rule over wives. For Boone novelistic form results from the tension between marriage as closure and obstructions to marriage, between social institutions and individual desires. Like Tanner, however, Boone posits a tension between antisocial desire and the social and literary forms that contain it. ${ }^{33}$

Trollope's narratives, by contrast, make the marriage plot a battle not between form and anti-form but between two social structures: hierarchical marriage and egalitarian marriage. Female romance is an element of both structures, since hierarchical marriage depends on female intimacy and egalitarian wedlock promotes female marriage. The triumph of hierarchical marriage is never a foregone conclusion in a Trollope novel: his narrators uphold male superiority and parental authority as traditional powers that can legitimately limit female autonomy, but they also advocate individualism, which mandates romantic love as the basis for marriage and requires that a woman freely choose her mate. Trollope's usual solution to this conflict is to characterize romantic love as its own form of compulsion for women. Like many Trollope novels, Can You Forgive Her? dilutes female romantic agency by insisting that Alice should feel compelled to marry John Grey because he loves her and she loves him, but unlike most Trollope novels, Can You Forgive Her? goes further and paralyzes its heroine's agency by showing that the task of choosing between male suitors flattens her into compulsive indecision.

Can You Forgive Her? divests romantic love of its contractual implications of individual choice by assimilating the two-suitor plot to a civilizational narrative that casts contractual marriage as primitive. Victorian social thinkers including Henry Maine, John Stuart Mill, Edith Simcox, and Mona Caird associated contract with modernity, civilization, and progress toward equality between women and men. Trollope, however, represents contract as a primitive form of violent compulsion and hierarchical

\footnotetext{
${ }^{33}$ See Joseph Allen Boone, Tradition Counter Tradition: Love and the Form of Fiction (Chicago: Univ. of Chicago Press, 1987), pp. 59, 66.
} 
marriage as eminently civilized in its amalgamation of forgiveness and punishment. From the novel's outset George is described as savage and primitive, a "wild man" (p. 56), "uncommonly dark" (p. 191), proudly wearing a facial scar that evokes ethnographic accounts of scarification among primitive tribes. His scar, a "black ravine running through his cheek" (p. 75), symbolizes primitive violence with a semiotic directness that was itself considered a hallmark of primitive sign-systems, for when George is angry his scar "seem[s] to open itself and to become purple with fresh blood stains" (p. 550). As the novel progresses George becomes a "wild beast" (p. 596) who makes "assaults upon [Alice's] purse" (p. 49o), entertains murderous wishes, and becomes a figure of real violence in three separate attacks on Alice, Kate, and John Grey. Even his speech becomes primitive, issuing from him "with a stigmatizing hiss" (p. 496), and his behavior toward Kate and Alice exemplifies what Victorians considered the male savage's tendency to press the advantage of superior strength.

George's contempt for a former mistress in chapter 71 (pp. 734-44) similarly exhibits the callousness of a polygamist who refuses to abide by marriage laws, and his "hard ferocity" and "hatred, as he called it, of conventional rules" mean that he is "controlled by none of the ordinary bonds of society" (p. 58o). The narrator calls George's dislike of convention "Bohemian" (p. 329), a term that marks George's lawlessness as simultaneously primitive and hypermodern. An avant-garde belief in "the absurdity of ... indissoluble ties" (p. 330) makes him both like a "heathen" and "almost inclined to think that marriage was an old-fashioned custom . . . not adapted to his advanced intelligence" (p. 329). By describing George's "advanced intelligence" as an attempt "to imitate the wisdom of the brutes" (p. 330), the narrator equates the modern idea of dissoluble ties with George's violence and promiscuity. Thus when George confronts John in his lodgings, he presents contract (written agreements) and violence (physical fighting) as two sides of the same coin: "You shall either give me your written promise never to go near [Alice] again, or you shall fight me" (p. 748). Rather than a genuine alternative to primitivism, contract becomes its counterpart. 
The novel's most vivid reduction of the contractual to the primitive takes place when George sends his clerk to Alice and she signs the notes that he presents under almost Gothic duress. The narrator describes George's emissary as a primitive incursion into Alice's drawing-room: "Mr Levy was certainly not a gentleman of the sort to which [Alice] had been most accustomed. He was a little dark man, with sharp eyes, set very near to each other in his head, with a beaked nose, thick at the bridge, and a black moustache, but no other beard. Alice did not at all like the look of Mr Levy" (pp. 627-28). Mr. Levy's looks recall George's - both men are dark and wear moustaches - and his replacement of George at Alice's side identifies contract-like the Jew for the anti-Semite - as the point where modernity becomes primitive. Instead of being associated with equality, contract becomes linked to exploitation when the bill Alice signs is cashed by "a Jew bill-discounter" for an unfairly low amount (p. 734).

The narrator's commitment to hierarchical marriage, however, means that even as he condemns George's violence as the primitive outcome of the excessive modernity of contract, he asserts that violence has its proper place in traditional marriage. When George breaks Kate's arm, the narrator comments that men should not strike women; but since marriage is permanent, "a wife may have to bear [a blow] and to return" (p. 6oo)-suggesting that George's violence would be acceptable if exercised from within an indissoluble marriage. As the prelude to John's final, successful wooing of Alice, George's blatant aggression makes John's milder coercion seem more palatable. John's gentle force comes to seem necessary in order to preserve Trollope's conservative ideal of innovation without revolution, an ideal rendered even more appealing in contrast to the havoc wreaked by the radical, bohemian George.

The novel denigrates contractual marriage by means of a complex financial subplot calculated to absolve the man who represents hierarchical marriage of any possible charge of theft. Feminists accused the law of coverture of allowing husbands to steal their wives' property, but Can You Forgive Her? depicts contractual, dissoluble agreements as posing the greatest danger to a woman's wealth. Apprised of Alice's transactions 
with George, John Grey works to nullify her contracts, colluding with her father so that John, not Alice, pays George the money promised by her signed bills. Although John, if Alice marries him, will be subject to the law that gives the husband his wife's assets upon marriage, he demonstrates indifference to his economic interests by willingly giving up his own money in order to preserve Alice's wealth after she dissolves their engagement.

For George's economy of contractual exchange John substitutes gift and sacrifice, generously asserting his superior wealth and power by spending his own money so that Alice can keep hers and be indebted to him. Ultimately, however, the political economy of marriage cancels any gift between husband and wife. John promises Alice's father that he will allow himself to be repaid if he and Alice do not ultimately marry (p. 642), and once he marries Alice, John owns the wealth that he had protected. Despite his best intentions, his gift returns to him in a circuit that fulfills the novel's deeper intention: to guarantee that Alice does not contract to give away money of her own free will but instead loses it through subjection to the law. When Alice learns of John's secret plot to pay the notes that she had signed, she insists that "he must be paid"; but her father, in a statement that syntactically effaces any trace of Alice's financial agency, reminds her that marriage will automatically cancel her debt: "Paid! . . . he can pay himself now" (p. 798).

The coverture and coercion that feminist contemporaries labeled relics of primitive marriage become necessary elements in Can You Forgive Her?, which almost seems to revel in the fact that its heroine must be compelled to marry. ${ }^{34}$ In order to make compulsion palatable as such, the narrator represents it in terms of figurative, ethically justified violence. Immediately before John's final proposal, the narrator explains that Alice

\footnotetext{
34 On the compulsory nature of marriage in this Trollope novel and others, see Margaret Hewitt, "Anthony Trollope: Historian and Sociologist," British Journal of Sociology, 14 (1963), 226-39; George Levine, "Can You Forgive Him? Trollope's 'Can You Forgive Her?' and the Myth of Realism," Victorian Studies, 18 (1974), 5-30; Christopher Herbert, "He Knew He Was Right, Mrs. Lynn Linton, and the Duplicities of Victorian Marriage," Texas Studies in Literature and Language, 25 (1983), 448-69; King, "Certain Learned Ladies," p. $3^{16}$; and Flint, "Introduction: Trollope and Sexual Politics," p. xxvii.
} 
feels too guilty over having previously jilted John to allow herself to take him back: "as far as she could decide at all, she decided against her lover. She had no right of her own to be taken back after the evil that she had done, and she did not choose to be taken back as an object of pity and forgiveness" (p. 766). Alice associates her decision not to marry John with her autonomy: she has "no right of her own" to marry him and does not "choose" to be forgiven by him. John must overcome that autonomy, and he approaches Lucerne "confident that he would, at last, carry his mistress off with him to Nethercoats" (p. 637) - an allusion to primitive marriage by capture that adumbrates the violence of his actual proposal.

In Can You Forgive Her? the space in which one coerces one's self is the space of both contract and guilt, and because Trollope understands that space as sustaining the heroine's will, he refuses to allow her to abide in it. ${ }^{35}$ John responds to Alice's belief that her guilt prevents her from marrying him by insisting that his conscience replace hers. His proposal does not ask for her consent but requires it: "And am I to be punished, then, because of your fault? ... If you love me, ... I have a right to demand your hand. My happiness requires it, and I have a right to expect your compliance. I do demand it. If you love me, Alice, I tell you that you dare not refuse me" (p. 771). John's words meld compulsion and romance, and primitive and companionate marriage, by citing love as the premise of his intimidating demand for compliance ("If you love me, ... you dare not refuse me"). His figures of speech emphasize Alice's physical surrender rather than her verbal assent ("I have a right to demand your hand"), and his appropriation of her body subsumes the marriage ceremony's verbal assent within his own assertions: John's "I do demand it" contains, anticipates, replaces, and thus erases Alice's "I do."

It is significant that Alice never says to John that she will be his wife. Her initial response to his demand is wordlessness: "Alice sat silent beneath his gaze, with her eyes turned upon

35 James Kincaid notes that, in being asked to forgive Alice, "we are asked to participate in a very ironic forgiveness, asked, in other words, to assist in the suppression of her will" (Novels of Anthony Trollope, p. 187). Kincaid observes that Alice holds on to her guilt and refuses forgiveness because "as long as she can maintain her grip on this guilt, she can, of course, elude Grey" (p. 186). 
the tombstones beneath her feet" (p. 771). The equivalence between Alice as the subject of John's gaze and the tombstones on which she focuses her own gaze underscores that the marriage he proposes is the death of her will. A sentence immediately follows - "Of course she had no choice but to yield" (p. 771 ) -whose meaning is initially ambiguous because it has two possible sources. As an announcement of the narrator's views, this statement hovers between statement and command; as a report of Alice's thoughts, it is a resigned observation. The ambiguity is resolved when the narrator, several sentences later, conveys Alice's internal acquiescence to John's superiority: "she had always felt that to yield to him would be to confess the omnipotence of his power. She knew now that she must yield to him, - that his power over her was omnipotent. She was pressed by him as in some countries the prisoner is pressed by the judge" (p. 772). The word "pressed" underscores the equation of speech and violence, and the comparison between Alice and a prisoner echoes an earlier remark comparing the recalcitrant Alice to "a prisoner who would fain cling to his prison after pardon has reached him" (p. 771).

Alice will be a prisoner if she marries and if she does not, and the marriage that promises to liberate her from the circular indecision in which she has trapped herself encloses her even more thoroughly in John's power. Like a prisoner, Alice remains silent: "the word which she had to speak still remained unspoken" (p. 772). John provides the only gesture that signifies agreement to his proposal: "gradually he put his arm round her waist. She shrank from him, . . . but she could not shrink away from his grasp. She put up her hand to impede his, but his hand, like his character and his words, was full of power. It would not be impeded" (p. 772). Alice's only assent to John's proposal is nothing more than a recognition of his superior strength, which she acknowledges even as she attempts to escape its grip: "You win everything, - always,' she said, whispering to him, as she still shrank from his embrace” (p. 772).

In order to justify the violence of marriage by capture, Can You Forgive Her? grafts violence onto an ethics of guilt and forgiveness. Compulsory marriage becomes a matter of conscience-which is not to say that Alice simply marries out of 
guilt. Rather, the novel requires her to relinquish her guilt so that she can marry; John's forgiveness does not establish Alice's guilt but deprives her of it. The novel recasts the marriage plot in terms of injury and forgiveness: first a woman injures a man by breaking her promise to marry him, then she feels guilt, and finally her guilt dissolves when she receives her future husband's forgiveness. To refuse to accept forgiveness is thus to obstruct marriage, as Alice does just before John demands her hand at Lucerne. Alice tells him: "though you may forgive me, I cannot forgive myself. . . . I have done that which makes me feel that I have no right to marry anyone. . . . I know that it will be better . . . that I should remain as I am" (p. 732). To accept forgiveness in the form of the husband who grants it is also to accept the superiority of the one who forgives, since forgiveness is a prerogative of the strong. When Plantagenet Palliser forgives Glencora, the narrator remarks: "He was killing her by his goodness" (p. 616). After subjecting her prospective husband, Captain Bellfield, to a "cross-examination" in which he confesses all his faults, the formidable Mrs. Greenow "forgave him all his offences" (p. 674). Alice resists John's power of forgiveness because as long as she can maintain her guilt she defers marriage, manifests her will, claims equality with John, and remains attached to contract.

We associate Friedrich Nietzsche today with a philosophical conversation about which Victorian novelists had little to say, but Nietzsche begins On the Genealogy of Morals (1887) as an attack on "English psychologists" whose anthropological histories of morality equated civilization with contracts that outlawed violent penalties and created equality between the weak and the strong. ${ }^{36}$ Nietzsche's polemic against those English thinkers argued that contract merely replaces punishment with promises and trades primitive sacrifice for guilt. The bad conscience of guilt turns retaliation for injury into a contract between debtor and debtee; just as the primitive culprit's bodily pain repays the

36 See Friedrich Nietzsche, On the Genealogy of Morals, trans. Walter Kaufmann and R. J. Hollingdale, in Nietzsche, "On the Genealogy of Morals" and "Ecce Homo," ed. Kaufmann (New York: Vintage Books, 1967), p. 24. Nietzsche singles out Henry Thomas Buckle (see On the Genealogy of Morals, p. 28), who wrote a popular History of Civilization in England (1857-61). 
injury that she has done, so too the modern wrongdoer honors a contract that stipulates that reparation for wrongdoing must take the form of suffering from a bad conscience. Guilt becomes a sign of debt and contract because it signifies the painful consequences of not honoring one's promises, for the essence of contract is not keeping one's promises but agreeing to pay damages if one revokes agreements. ${ }^{37}$ Nietzsche describes the modern pain of conscience as "imaginative and psychical" (p. 68), a private pain witnessed only by the self observing itself (p. 69); it is the result not of the noble primitive's truly free will but of an " $\mathrm{in}$ stinct for freedom forcibly made latent . . . pushed back and repressed, incarcerated within and finally able to discharge and vent itself only on itself" (p. 87). Guilt is "a madness of the will" in which one punishes oneself "without any possibility of the punishment becoming equal to the guilt" (p. 93).

Those words so aptly describe Alice because Nietzsche, like Trollope, sought to overturn the received idea that modernity is superior to the past it replaces, although each man pursued his critique of modernity along very different lines. Nietzsche's glorification of body over soul and force over weakness attacked the premises of Christianity, while Trollope aimed to integrate force and hierarchy into a Christian framework of conscience, forgiveness, and expiation. Can You Forgive Her? effects that integration by sanctioning the use of force to compel Alice to give up her guilt about jilting John so that she can allow herself to be forgiven and marry him. Alice's bad conscience represents her insistence that she punish herself rather than accept John's right to forgive or punish her. The narrator terms this "a perverseness of obstinacy, a desire to maintain the resolution she had made ... that she might be allowed to undergo the punishment she had deserved" (p. 771). Just before John proposes in Lucerne, Alice thinks of forgiveness as an imposition of his power on hers: "she did not choose to be taken back as an object of pity and forgiveness" (p. 766). John similarly associates Alice's renunciation of guilt with obedience to him; the narrator notes that Alice is full of "self-accusation," but he tells us: "she would not . . have been more willing to obey him in that one point, as to which he

37 See Nietzsche, On the Genealogy of Morals, p. 65 . 
now required present obedience. [John] understood that she must be taught to forgive herself . . . before she could be induced to return to her old allegiance to him" (p. 755).

Forgiveness annuls the egalitarian possibilities of contract and formalizes the coercion embedded in hierarchical marriage. By compelling Alice to accept his forgiveness as authoritative, John forces her to give up her contract with herself to remember the injury she had inflicted on him, a contract that also memorialized her will to power. His forgiveness does not end Alice's punishment; it simply transfers the punishing agency from Alice to others. As Alice wryly notes, "There is a forgiveness which it is rather hard to get" (p. 799). The narrator underscores that hardship with lurid figures of violence that describe how Alice must accept the "punishment . . . inflicted on her" and "acknowledge ... to herself . . that she deserved all the lashes she received" (p. 822). For Alice to accept forgiveness is to accept the power of others to subject her to their punishments and their wills: "there was nothing left for her but to do as others wished” (p. 815). The title's invitation to the reader to forgive Alice thus becomes an invitation to participate in her punishment.

Formal analyses of the marriage plot usually focus on the reader's desire for closure, but Can You Forgive Her? suggests that the desire for a marital conclusion does not go without saying, given the striking maneuvers that the narrator must use to end up there, particularly in his use of free indirect discourse and first-person narration. ${ }^{38}$ Trollope frequently uses free indirect discourse, in which a character's inner thoughts merge with the voice of the narrator who reports them: "What had she wanted in life that she should have thus quarrelled with as happy a lot as ever had been offered to a woman?" (p. 177). While Trollope's deployment of free indirect discourse strives for the transparency associated with psychological fiction, his version in this novel lacks the irony usually attributed to those of Jane Austen

${ }^{38}$ For classic accounts of narration in Trollope, see Kincaid, Novels of Anthony Trollope, p. 3; Levine, "Can You Forgive Him," p. 14; and Robert M. Polhemus, The Changing World of Anthony Trollope (Berkeley and Los Angeles: Univ. of California Press, 1968), pp. $5^{-6 .}$ 
and Gustave Flaubert, because Trollope's narrator constantly supplements seamless ventriloquism of his characters' thoughts with obtrusive narrative comments: "Poor Alice! I hope that she may be forgiven" (p. 177). As the ultimate arbiter of the accuracy of his characters' thoughts, the narrator of Can You Forgive Her? makes his moral authority inseparable from his reportorial trustworthiness; it is because he knows the facts of Alice's life that he knows what to make of them. As a judge of Alice's behavior, the narrator is also in a position to forgive her, and to solicit and demand the reader's forgiveness as well: Alice "knew that she could not forgive herself. But can you forgive her, delicate reader? .. . For myself, I have forgiven her. . . . And you also must forgive her before we close the book, or else my story will have been told amiss" (p. 398). Alice's resistance to hierarchical marriage mirrors the "delicate" female reader's resistance to the narrator, and the marriage plot can achieve closure only when all resistance ceases and characters, reader, and narrator all agree to Alice's forgiveness. Hence the marriage plot concludes when the narrator's representations of Alice's thoughts show that her conscience is no longer her own but his. Immediately before the churchyard scene, the narrator reports Alice's thoughts: "She had left John Grey. . . . Of course she had been wrong. She had been very wrong. ... She knew that she had been wrong in both, and was undergoing repentance with very bitter inward sackcloth" (p. 718). Once Alice accepts John, the narrator uses the classic form of free indirect discourse; narratorial commentary is no longer necessary once Alice's thoughts coincide with the narrator's.

The narrator's presence in Alice's mind creates a further complication, however, since her internalization of the narrator's dictates compromises the goal that he seeks to achieveAlice's complete acceptance of John as her sole guide. The narrator thus makes a startling appearance in the churchyard proposal scene in order to cede Alice to her betrothed. Throughout the novel the narrator often speaks in the first person, but he rarely situates himself in the characters' space and time or claims their ontological qualities. The narrator displays his psyche through the medium of his characters; we know him through his descriptions of them, not of himself. Yet just before 
John demands Alice's hand, the narrator uncharacteristically speaks in the present tense and places himself with his characters in the churchyard, which he describes:

It is one of the prettiest spots in that land of beauty; and its charm is to my feeling enhanced by the sepulchral monuments over which I walk, and by which I am surrounded, as I stand there. Up here, into these cloisters, Alice and John Grey went together. (p. 767 )

After compelling Alice to replace her judgments with his own, the narrator leaves her to John's direction and guidance by momentarily becoming a character. Using the more immediate "these" instead of "those," gratuitously repeating "I" three times, and making startling use of the present tense, the narrator asserts a presence coterminous with those of the novel's characters. This auto-personification disrupts narrative conventions in order to trope the narrator as the man who gives Alice to John in marriage; narratorial coverture makes way for marital coverture. In the final sentence above, the narrator shifts almost seamlessly from asserting his own presence in the scene ("up here, in to these cloisters") to designating "Alice and John Grey." Named as a marital unit, "Alice and John Grey" move away from the narrator and back into the novel's customary past tense ("went together"); now safely under John's direction, Alice can recede from the narrator's control.

Precisely because Can You Forgive Her? exposes the arduous work required to make Alice's wishes coincide with John's and with the narrator's, it does not fully naturalize hierarchical marriage. Narrative technique can veil the paradox of a hierarchical marriage that demands consent, but it cannot dissolve it. Trollope's novel registers the Victorian awareness that marriage as contract, a free agreement between equals, might undo differences between men and women and transform marriage into a union between any two or even any three people. Trollope's hectoring title, which challenges readers to rise to the occasion and forgive all of the women interpellated by its feminine pronoun, encapsulates the novel's recoding of force as ethics, commands as questions: not "you must forgive her," but "can you forgive her?" Critics have always assumed 
that insofar as the title refers to Alice, it asks the reader to forgive her for rejecting the right man for the wrong one. But the reader of "Among the Fells" knows that the book also asks us to forgive Alice for assenting to a marriage proposal from Kate. By construing the reader who cannot forgive as hard-hearted, churlish, and even unchristian, Trollope makes it difficult to answer "no" to his title question; but by posing his title as a question, he creates the possibility of a negative response. Although John does not take no for an answer when he proposes marriage to Alice, Trollope can image a dissenting reply to the question that his title poses. To refuse to forgive Alice and Kate for the marriage that they willingly contemplate is also to refuse to forget them, to refuse to treat their desire for female marriage as an anomaly, an object of pity, or a punishable offense. Far from being a disruption of narrative and social forms, the female marriage that contracts to a memory at the novel's end attests to the plasticity of norms perpetually under construction and always subject to reform.

\section{Columbia University}

\section{ABSTRACT}

Sharon Marcus, "Contracting Female Marriage in Anthony Trollope's Can You Forgive Her?” (pp. 291-325)

This essay demonstrates that Anthony Trollope was one of several Victorians aware of "female marriage," a term that Elizabeth Barrett Browning used to describe committed unions between women. After establishing that Trollope knew women in female marriages at the time that he was composing his novel Can You Forgive Her? (1864-65), the essay analyzes how female marriage inscribes itself within the form of the marriage plot. Trollope's novel aligns female marriage with contractual marriage, associated with feminist demands to make unions between men and women more egalitarian as well as dissoluble. The novel works to discredit contractual forms of marriage and to celebrate indissoluble hierarchical marriage by associating the first with primitive savagery, the second with an ideal of civilization that can accommodate male violence. 